\title{
Potential of shea fruit-based ingredients for the feed industry
}

\author{
Martin Ntiamoah Donkor ${ }^{1 *}$ (D), Richard Mosobil ${ }^{1}$, Eunice A. Abaah ${ }^{1}$, Cephas Kanati ${ }^{1}$, Fortune Akabanda ${ }^{2,4}$ (D) and \\ Addai-Mensah Donkor ${ }^{1,3}$
}

\begin{abstract}
Background: The cost involved in feeding poultry is very high especially in most developing countries. To this end, the effectiveness of the fruit pulp of Vitellaria paradoxa (shea), an agro-industrial by-product that is discarded in the processing of the nut for shea butter extraction was investigated on twelve poultry birds assigned to three groups $A$, $B$ and C (control). Dried samples of the fruit pulp were analysed for their nutrients.

Results: Proximate analysis of the shea fruit pulp revealed a carbohydrate content of $41.14 \%$, crude fibre $26.62 \%$, crude protein $10.34 \%$, ash $9.23 \%$, crude fat $3.55 \%$ and $9.13 \%$ for moisture. It also contained essential minerals such as Ca (587 mg /100 g dw), Na (138.30 mg /100 g dw), Mg (1358 mg /100 g dw), K (771.5 mg /100 g dw), Fe (29.88 mg/100 g dw), Zn (40.31 mg/100 g dw) and Cu (8.11 mg/100 g dw). Heavy metals such as Cd, Mn, Pb and Cr were below detectable limits. Measured parameters were live body weights and some selected blood chemistry tests. Broilers in groups $A$ and $B$ fed on shea fruit pulp formulated with maize meal showed a significant growth performance in weight $(p<0.05)$ as compared to group $C$ fed on maize meal only. Selected blood chemistry tests carried out included $\mathrm{Ca}$, Na, K, Albumin, Triglyceride and Chloride. Statistical analysis showed that formulated feed had a significant effect $(p<0.05)$ on blood chemistry values of broilers, however, there was an insignificant effect $(p>0.05)$ in the control group, fed on maize meal only.
\end{abstract}

Conclusion: The fruit pulp of Vitellaria paradoxa could be considered a good source of macro and micronutrients and could be used as a supplement in poultry feed.

Keywords: Vitellaria paradoxa, Proximate analysis, Mineral composition, Serum, Poultry, Broilers

\section{Background}

The poultry industry is considered an important contributor to agriculture, accounting for $34.5 \%$ of the total gross domestic product (GDP) of Ghana [1]. According to the Ministry of Food and Agriculture (MoFA) [2], the industry offers prospects for wealth creation, income enhancement, coping mechanism against crop failure, financial security and improvement in rural livelihoods.

\footnotetext{
*Correspondence: mdonkor@cktutas.edu.gh; dr.adonkor@uds.edu.gh ${ }^{1}$ Department of Applied Chemistry and Biochemistry, Faculty of Applied Sciences, C. K. Tedam University of Technology and Applied Sciences, Navrongo, Ghana

Full list of author information is available at the end of the article
}

The sector is increasingly gaining high recognition as the demand for poultry products as a source of protein has increased gradually [3]. In a study by Abu et al. [4], poultry meat and eggs account for about $10 \%$ of the total amount of meat and eggs produced in the world annually.

In developing countries such as Ghana, poultry rearing has been a practice for both rural and urban dwellers as a result of population growth, increased urbanization and rising income demands [5]. However, the sector is faced with many challenges ranging from increasing cost of feed to occasional feed shortages, hence threatening the broiler industry [6]. These challenges have been identified to be a key barrier to meeting the demand for animal protein in developing countries [7]. original author(s) and the source, provide a link to the Creative Commons licence, and indicate if changes were made. The images or other third party material in this article are included in the article's Creative Commons licence, unless indicated otherwise in a credit line to the material. If material is not included in the article's Creative Commons licence and your intended use is not permitted by statutory regulation or exceeds the permitted use, you will need to obtain permission directly from the copyright holder. To view a copy of this licence, visit http://creativecommons.org/licenses/by/4.0/. The Creative Commons Public Domain Dedication waiver (http://creativeco mmons.org/publicdomain/zero/1.0/) applies to the data made available in this article, unless otherwise stated in a credit line to the data. 
Considering the total cost of poultry feed, about $95 \%$ is essentially for energy and protein requirements, approximately $4 \%$ for major trace minerals and vitamins whiles $2 \%$ accounts for various feed additives [8]. As a result, poultry feed is adjudged as one of the greatest problems affecting the productivity and profitability of broiler production. The unavailability of the feed poses much frustration to many poultry farmers, which subsequently deters them from venturing into large-scale broiler business [9].

In order to ensure a sustainable supply of feed, attempts have been made to reduce the cost of feeding through the utilization of feed ingredients that are high in both carbohydrates and protein quality [10] including agro-industrial by-products [11]. This has necessitated the importance of exploring the use of non-conventional feed resources (NCFR) in livestock production systems. Namely, crop residues, agro-industrial by-products, leaf and seed meals such as the leaves and seeds of Gmelina arborea, slaughterhouse by-products, cassava leaf meal, browse foliage and many others, are potential NCFR that are available [12]. One of such NCFR that this study seeks to focus on is the fleshy fruit pulp of the Vitellaria paradoxa tree, an agro-industrial by-product. This research is aimed at contributing potentially to decreasing the cost of feeding devoid of an adverse effect on the performance of the broilers. The usage of the fruit pulp may also help to reduce pressure on conventional food items that are normally used in the feed industry thereby enhancing availability of more food for direct human consumption [4].

Vitellaria paradoxa, commonly called shea, is an indigenous African tree that grows especially in the savannah belt of West Africa [13]. The fruits, which are green and fleshy, are very sweet and edible. In Ghana, it is found in almost the entire northern part, covering a land area of about 77,650 $\mathrm{km}^{2}$ just like the locust bean (Parkia biglobosa) locally known as "dawadawa" and tarmarind tree (Tamarindus indica) [14]. The shea tree is a major source of income to the rural dwellers and it is preserved by the indigenes due to its high economic value [13]. The tree is well known as a dedicated source of shea butter, which is extracted from the kernels of the nut. Notwithstanding its economic value, it is essentially the main edible oil for the people of the northern part of Ghana [15], most especially amongst the rural folks. Shea butter also has a therapeutic application as an anti-inflammatory balm in healing bruises and dermatitis, in addition to its industrial usage in making moisturizing creams and lotions, as well as its utility in the manufacturing chocolate and soap $[15,16]$.

Research has shown that the leaves, flowers, roots and the bark of the shea tree are used in various ways. The leaf is reported to be used as vapor baths for headache [17]. Moreover, it is indicated that the root and stem bark are used to treat various ailments such as jaundice, diarrhoea and stomach ache. The fruit pulp is eaten as a food to boost food availability especially during the annual hunger seasons. The shea fruit pulp (SFP) has been found to contain carbohydrates $(41.3 / 100 \mathrm{~g})$, proteins (0.7$1.3 \mathrm{~g})$, ascorbic acid (196.1 mg/100 g), Fe (1.93/100 g) and $\mathrm{Ca}(36.4 \mathrm{mg} / 100 \mathrm{~g})[18-22]$. It is therefore believed that the fruit pulp is a potential feed resource and has an adequate nutrient equivalent to other edible fruits.

The extensively acknowledged dietary and socio-economic value of the shea nut for shea butter extraction seem to undermine any usefulness attached to the SFP. Although the nutritional and elemental composition, including proximate qualities of the SFP have been investigated [18-22], there is a dearth of information on the nutritive value of SFP on poultry. Thus, this study seeks to evaluate the nutritional components of SFP and its influence as a feed supplement on weight gain and other features on broilers.

\section{Materials and methods}

\section{Source of shea fruits and broiler chicks}

Shea fruits were gathered from Vunania within the Navrongo locality in the Kasena Nankana Municipality, Upper East Region of Ghana. Four (4) weeks old male broiler chicks as well as maize were purchased from the Navrongo market.

\section{Sample preparation and feed formulation}

Fresh whole shea fruits were de-pulped and the fruit pulp comprising the epicarp and mesocarp were sundried. Dried samples were reduced to powder using a mortar and a pestle. The maize was coarse ground using a plate attrition mill. Powdered SFP sample and maize were mixed thoroughly in a ratio of 1:5, thus one part of the SFP to five parts of the maize to derive the shea fruit pulp-maize meal (SFPMM).

\section{Management of broilers}

Twelve chicken broilers were allotted to floor pens (4:4:4) with respective identities A1, A2, A3, A4; B1, B2, B3, $\mathrm{B} 4$; and $\mathrm{C} 1, \mathrm{C} 2, \mathrm{C} 3, \mathrm{C} 4$ in a complete randomized block design. Sunlight was used as a source of light during the day and a lamp was used to illuminate the pens at night. The birds were kept under a deep litter management system and wood shavings were used as litter material which aided as an absorbent. 


\section{Feeding of broilers}

A single diet was formulated in two different phases at 3-week intervals. Broilers in block A were fed with SFPMM for the first 21 days while those in blocks $B$ and $C$ were given only maize meal (MM). After the first 21 days period, broilers in block $B$ were also given the same quantity of SFPMM for the next 21 days while those in blocks $\mathrm{A}$ and $\mathrm{C}$ were maintained on MM only. Broilers were made to acclimatize to the experimental diet for a period of four weeks prior to data collection. Broilers were provided with rations twice daily at intervals of $10 \mathrm{~h}(7: 00 \mathrm{am}-5: 00 \mathrm{pm})$ and daily provision of clean water.

\section{Weighing of birds}

Employing digital top-loading balance (A \& D GF-3000, Cole-Parmer Ltd, USA), initial weight of each bird was recorded before the study began and during the study at three days interval before feeding in the morning.

\section{Average daily weight gain per bird}

The method employed by Onyimonyi et al. [23] was used to estimate the average daily weight gain per bird (ADWG). This is represented by the expression:

$$
\mathrm{ADWG}=\frac{\mathrm{TW}_{\mathrm{f}}-\mathrm{TW}_{\mathrm{i}}}{\mathrm{d}_{\mathrm{n}} \times \mathrm{n}_{\mathrm{r}}}
$$

where, $T W_{f}=$ total weight of the birds at the end of the period; $T W_{\mathrm{i}}=$ the total weight of the birds at the beginning of the study; $d_{n}=$ number of experimental days; $n_{r}=$ number of birds per replicate.

\section{Blood sample collection}

Blood samples of the birds were collected by a trained and qualified veterinary officer at the Navrongo Veterinary Clinic. Through the veins in the wings of the birds, blood was taken from each bird using new $2 \mathrm{~mm}$ medical needles and syringes. After collection, a clean dry cotton was placed over the venipuncture site and wing closed to maintain pressure to stop the accumulation of blood under the vein. Starting with group A through $\mathrm{C}$, each broiler was bled and its blood released into the appropriate vacutainer test tube (BD Vacutainer ${ }^{\circledR}$, Franklin Lakes, USA) with corresponding identities. Selected blood chemistry parameters were carried out at Iqurate Laboratory Consult Limited in Bolgatanga, Upper East Region, Ghana. The parameters of interest estimated included $\mathrm{Ca}, \mathrm{Na}, \mathrm{K}$, chloride, albumin and triglyceride.

\section{Physical features of broilers}

The beaks, legs, combs, and wattles of birds were observed for any color change as well as their activeness.

\section{Determination of proximates, essential minerals and heavy metals in shea fruit pulp}

Proximate analysis was carried out to estimate crude fibre, crude lipid, crude protein, carbohydrate, ash and moisture content in the fruit pulp. Some essential minerals including $\mathrm{Ca}, \mathrm{K}, \mathrm{Na}, \mathrm{Mg}, \mathrm{P}, \mathrm{Zn}, \mathrm{Cu}, \mathrm{Mn}$, and $\mathrm{Fe}$, heavy metals such as $\mathrm{Pb}, \mathrm{Cd}, \mathrm{Cr}$ and $\mathrm{Mn}$ were determined. All analyses were carried out in duplicate except for protein, which was done once. Analysis was done according to Association of Official Analytical Chemists (AOAC) procedure [24]. All analysis was based on dry weight $(\mathrm{dw})$ of samples.

\section{Determination of moisture content}

This method was based on moisture evaporation [25]. A petri dish was washed and oven dried at a temperature of $110{ }^{\circ} \mathrm{C}$ and was allowed to cool in a desiccator. The weight of the petri dish (W1) was taken by means of precision balance (Sartorius CP224 S, Cole-Parmer Ltd, USA). Dried powdered SFP, $5 \mathrm{~g}$, was weighed into the petri dish (W2). The contents were then transferred into an oven at a temperature of $110^{\circ} \mathrm{C}$ for $4 \mathrm{~h}$. Subsequently, the sample was allowed to cool to room temperature and its weight taken again and then transferred into the oven once more at $110{ }^{\circ} \mathrm{C}$. The process was repeated until a constant weight was attained (W3). The percentage moisture was then calculated as:

$$
\% \text { Miosture content }=\frac{\text { loss in weight }(\mathrm{g})}{\text { weight of sample }(\mathrm{g})} \times 100 \%
$$

$$
=\frac{(W 2-W 3)}{(W 2-W 1)} \times 100 \%
$$

\section{Determination of ash content}

Ash represents the inorganic component (minerals) of the sample after all the moisture as well as the organic components have been removed. The method is based on the decomposition of all organic matter such that the mineral elements would not be lost in the process. A porcelain crucible was weighed and its weight noted as $W 1$. Powdered SFP, $2 \mathrm{~g}$, was weighed into the crucible and its weight recorded as $W 2$. The sample was ignited in a muffle furnace at a temperature of $60{ }^{\circ} \mathrm{C}$ for $2 \mathrm{~h}$ and cooled in a desiccator. Increase in temperature led to the rapid escape of moisture from the sample's texture and thus 
dried the product [26]. The weight of the ash sample was taken as W3. The ash content was calculated as:

$$
\% \text { Ash content }=\frac{(\mathrm{W} 2-\mathrm{W} 3)}{(\mathrm{W} 2-\mathrm{W} 1)} \times 100 \%
$$

\section{Determination of crude fat}

The method employed was the Soxhlet Extraction technique [27]. A round bottom flask, $500 \mathrm{ml}$, was thoroughly washed, dried and its weight taken (W1). A sample of SFP, $5 \mathrm{~g}$, was wrapped in filter paper and placed in the extraction chamber of a Solvent Recovery Extractor (Soxhlet method) (Det-Gras N 2P 4002842, JP Selecta, Spain). Petroleum ether, $200 \mathrm{ml}$, was poured into the weighed fat-free flask which is attached to the extractor. The flask was placed on a heating mantle such that the petroleum ether refluxed. Cooling was achieved by a running tap connected to the extractor. Extraction was carried out for $4 \mathrm{~h}$ and the solvent was recovered. The flask containing fat was transferred into an oven at $105{ }^{\circ} \mathrm{C}$ and allowed to stand for $1 \mathrm{~h}$. The flask was then cooled and its weight taken (W2). The crude lipid (fat) was calculated as:

$$
\begin{aligned}
& \% \text { Crude fat }=\frac{\text { weight of extracted lipid }(g)}{\text { Weight of sample }(g)} \times 100 \% \\
& =\frac{(W 2-W 1)}{\text { weight of sample }} \times 100 \%
\end{aligned}
$$

\section{Determination of crude protein}

Total protein was determined using the Kjeldahl method [27], which is based on the determination of the amount of nitrogen present. Powdered sample, $0.5 \mathrm{~g}$, was weighed into a digestion tube. Sulphuric acid, $10 \mathrm{ml}$, and $0.1 \mathrm{~g}$ of a catalyst (selenium oxide plus copper sulphate) were added to the contents in the tube. The mixture was then allowed to digest in a fume cupboard until a clear colorless solution was observed. The solution was cooled and transferred into a $50 \mathrm{ml}$ volumetric flask and diluted with distilled water up to the mark. The diluted sample, $5 \mathrm{ml}$, was pipetted into a Kjeldahl flask. Boric acid $(5 \%, 10 \mathrm{ml})$ was pipetted and two drops of a mixed indicator (methylene blue and methyl red) were added into a cleaned $250 \mathrm{ml}$ conical flask. In a Kjeldahl distillation unit (Det-
The instrument was turned on to discharge the first round of alkaline solution $(\mathrm{NaOH}, 10 \mathrm{ml}$ per discharge). The instrument was then switched on for the distillation until a pink color of the indicator turned greenishyellow. The distillate, $100 \mathrm{ml}$, was collected for titration. The content of the conical flask was then titrated with $0.019057 \mathrm{M} \mathrm{HCl}$ and the endpoint was indicated by a color change from greenish-yellow to pink. The volume of the titer was noted and percentage crude protein was calculated as:

$$
\% \text { Nitrogen }=\frac{\text { dilution } \times \text { titre } \times \mathrm{N}(\text { acid }) \times 0.01401}{\text { weight of sample }} \times 100 \%
$$

$\%$ Crude protein $=\%$ Nitrogen $\times 6.25$

where; $N=$ the normality of the acid, and $0.01401=$ atomic weight of nitrogen.

\section{Determination of crude fiber in the powdered fruit pulp}

Fibre analysis was done using the Weende method [18, 28]. It involves hydrolyzing protein, starch and other digestible carbohydrates and fat out of the sample before proceeding with the analysis. Defatted sample, $0.5 \mathrm{~g}$, was weighed (W1) into a round bottom flask. Sulphuric acid $(1.25 \%, 100 \mathrm{ml})$ was added and the mixture allowed to boil on a water bath for $30 \mathrm{~min}$. The hot solution was quickly filtered and the insoluble residue was rinsed several times with distilled water to ensure it was acid free. The insoluble matter was transferred into the round bottom flask, followed by the addition of $\mathrm{NaOH}$ solution $(1.25 \%)$. The mixture was allowed to boil for another $30 \mathrm{~min}$, and was then filtered under suction, rinsed severally with distilled water to ensure it was base-free. The residue was then dried in the oven to a constant weight, and allowed to cool to room temperature. The weight (W2) of the dried residue was recorded, and the percentage of the crude fiber was calculated as follows:

$$
\% \text { Crude fibre }=\frac{(\mathrm{W} 1-\mathrm{W} 2)}{\text { weight of original sample }} \times 100 \%
$$

\section{Determination of carbohydrate}

The total carbohydrates content was determined by difference:

$$
\% \text { Carbohydrate }=100-(\text { crude protein }+ \text { crude fat }+ \text { crude fibre }+ \text { ash content }+ \text { moisture content })
$$

Gras N 2P 4002842, JP Selecta, Spain), the Kjeldahl flask containing the boric acid was placed under the collecting drip ensuring that the tip of the drip was submerged while the flask containing the solution was securely fixed.
Determination of essential minerals and heavy metals

Powdered sample, $1.0 \mathrm{~g}$, was transferred into a digestion tube of a block digester (Speedy Digester K-425, Buchy, Switzerland). Concentrated sulphuric acid, $4 \mathrm{ml}$, and 
nitric acid, $1 \mathrm{ml}$, were added, and the mixture was moved into a fume cupboard and allowed to stand for $2 \mathrm{~h}$ to digest. The colorless solution was diluted to a volume of $50 \mathrm{ml}$ using distilled water. $\mathrm{Ca}, \mathrm{K}, \mathrm{Na}$ and $\mathrm{Mg}$ were determined with a Flame Photometer (Jenway PFP7, Cole-Parmer Ltd, UK). $\mathrm{Zn}, \mathrm{Cu}, \mathrm{Mn}, \mathrm{Fe}, \mathrm{Pb}, \mathrm{Cd}$ and $\mathrm{Cr}$ were also estimated using Atomic Absorption Spectrophotometer (novAA 400Plus, Analytik Jena, Germany).

\section{Statistical analysis}

The results generated were analysed with GraphPad Prism for Windows, Version 8 (GraphPad Software Inc, San Diego, CA, USA) using analysis of variance (ANOVA) followed by Tukey post hoc test. The significance level was set at $p<0.05$.

\section{Results and discussion}

The current study is the first of its kind to determine the effect of the Vitellaria paradoxa fruit pulp on poultry (broiler chickens). During the course of the research work, data were obtained based on different parameters under the following: proximate analysis and essential mineral assessment of SFP, selected blood chemistry test of the broilers on the first 21 days and on the 42nd day, variable weight measurements and observation of any physical changes during the period of study on the birds.

\section{Bodyweight gained}

Performance response to dietary treatments of broilers regarding their weight is shown in Fig. 1. Group A showed a gradual increase in body weight from the $0^{\text {th }}$

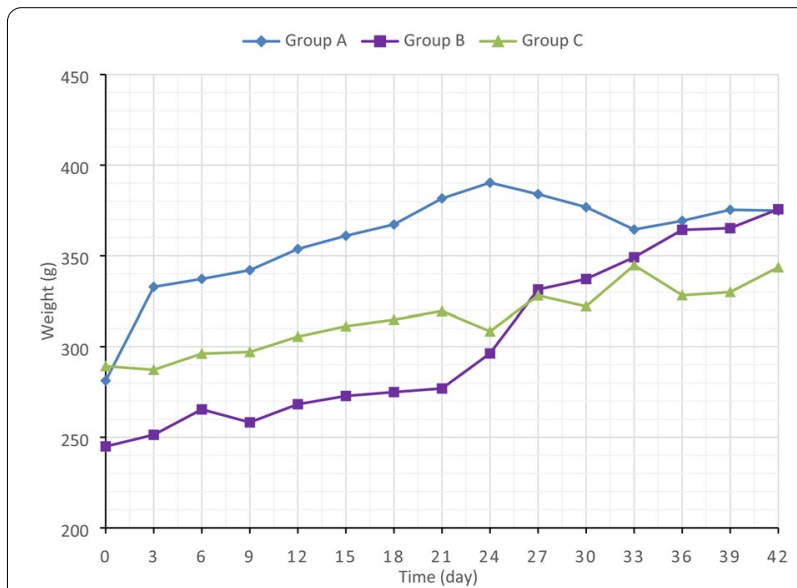

Fig. 1 Weight variation of Broilers. Group A = Fed with SFPMM for the first 21 days, then swapped with MM for the last 21 days; Group $B=$ Fed with MM for the first 21 days, them swapped with SFPMM for the last 21 days; Group C = Fed with MM throughout the 42 days period day that peaked at the 24th day, followed by a steady decline up to the 33rd day, and then a constant weight up to the 42nd day. Broilers in Group A were fed with SFPMM for the first 21 days, after which the feed was swapped with MM only for the next 21 days. The steady increase in body weight up to the 24th day, when SFPMM was swapped with MM, could be attributed to the nutritional minerals which persisted in the body. It is, therefore, reasonable to indicate that SFP could have impacted on the weight of the broilers fed with SFPMM through the delivery of vital biochemical minerals which might have been lacking in the normal diet of MM, compared with the slow weight gain progression for the control Group $C$ broilers.

Considering broilers in Group B, initially the birds were fed with only MM for the first 21 days before swapping to SFPMM. There was a gradual increase in body weight for the first 21 days. This observation of initial body weight gain could be attributed to a few nutritional minerals in the MM, which might have also influenced significantly the absorption of high nutritional mineral content in the SFP, making broilers in Group B exhibiting a considerable weight improvement when feedstuff was supplemented with SFP. SFP may have improved the feed efficiency, which resulted in increased body weight gain.

The mean weight of broilers in Group A $(359.45 \pm 27.61 \mathrm{~g})$ was significantly high $(p<0.05)$ compared to Group B $(302.13 \pm 46.35 \mathrm{~g})$ and Group C

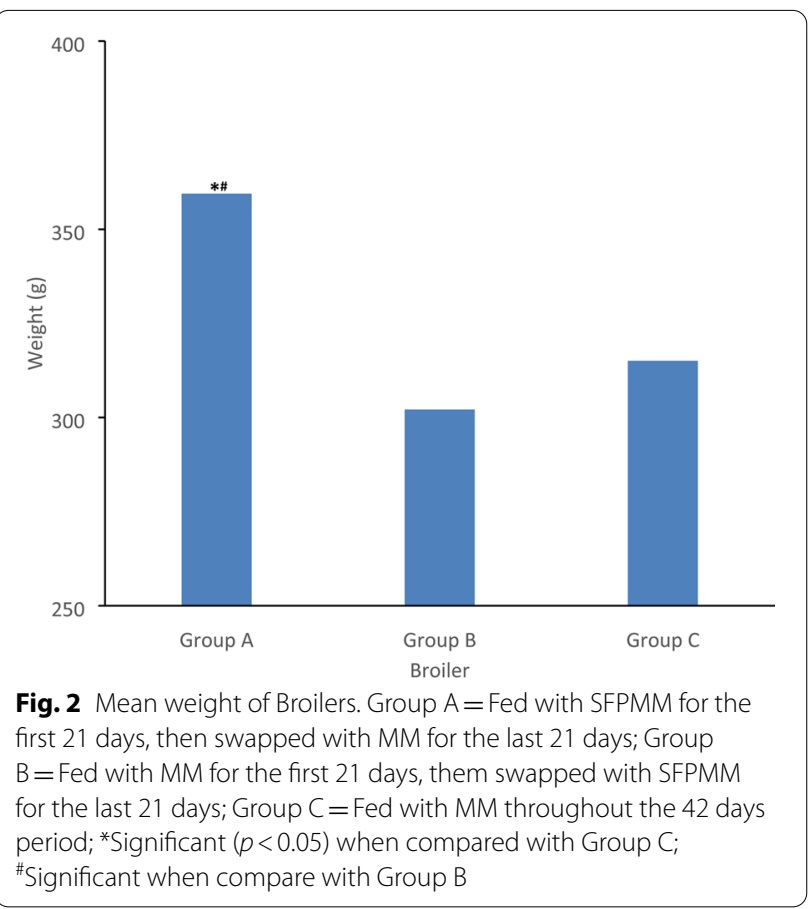




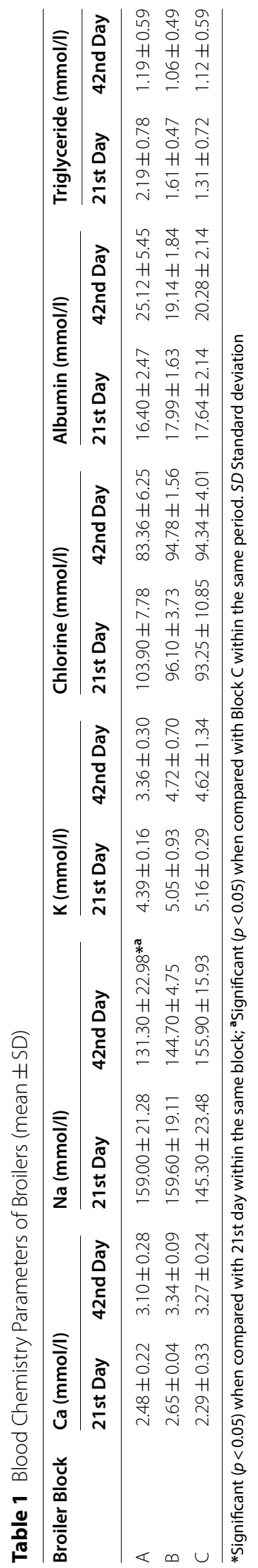




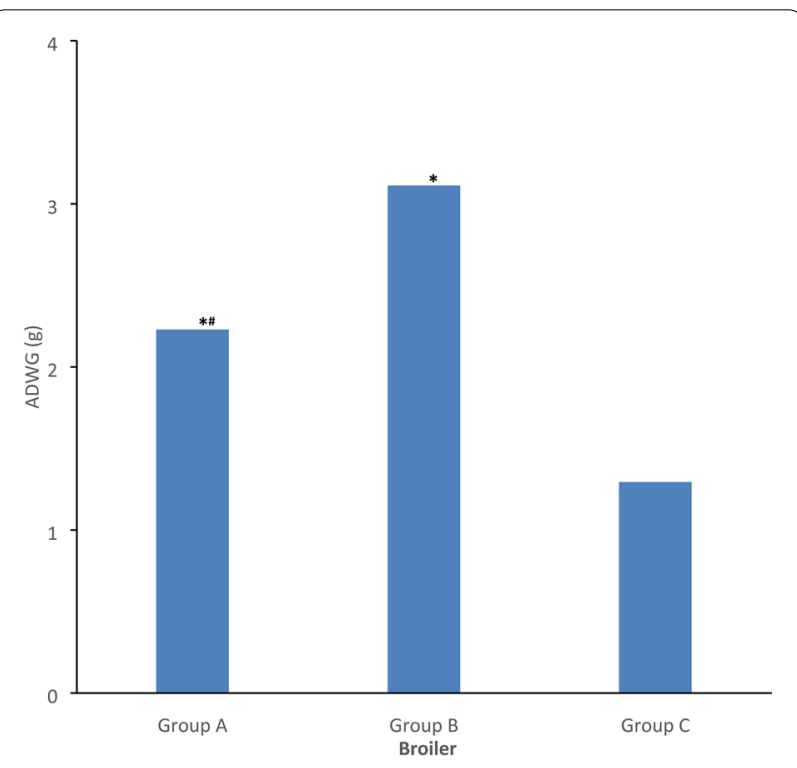

Fig. 3 Average Daily Weight Gained Per Broiler (ADWG). Group $A=$ Fed with SFPMM for the first 21 days, then swapped with MM for the last 21 days; Group B = Fed with MM for the first 21 days, them swapped with SFPMM for the last 21 days; Group $C=$ Fed with MM throughout the 42 days period; * Significant $(p<0.05)$ when compared with Group C; \#Significant when compare with Group B

$(315.06 \pm 18.13 \mathrm{~g})$. The mean weights of Group B and Group C were significantly the same $(p>0.05)$ (Fig. 2). However, the average daily weight gained per bird (ADWG) in Group A broilers $(2.23 \pm 0.12 \mathrm{~g})$ was significantly lower $(p<0.05)$ than in Group B $(3.11 \pm 0.02 \mathrm{~g})$, but higher compared with Group C $(1.30 \pm 0.21 \mathrm{~g})$ (Fig. 3).

Generally, feed consumption is closely associated with growth performance in broilers [29]. Decrease in the weights could be attributed to stress factors such as thermal as well as transportation stress. Findings of Rhoads et al. [30], Koelkebeck [31] and Sohail et al. [32] attest that heat stress causes low feed intake in poultry, which affects weight gain. Growth rate, metabolism and immunity are other parameters that heat stress can affect negatively [33]. One study indicated that birds fed with high levels of fiber increased feed intake but did not increase body weight gain and concluded the fiber might have served as a diluent in their trial even though the feeds were formulated to be isoenergetic [34].

Previous research indicates that regarding the expected fiber concentration, a $10-15 \%$ variation in analysis is considered acceptable $[34,35]$. It is widely accepted that dietary fiber affects gastrointestinal tract development, gut morphology and enzyme secretion, nutrient digestibility and absorption in poultry [36].

\section{Blood chemistry}

The current work revealed that with the exception of the concentration of $\mathrm{Na}$ being significantly $(p<0.05)$ high in Group A compared with Group $C$ on the 42nd day, there was no significant $(p>0.05)$ variation in all the blood chemistry parameters within a period for a particular group, and between the broiler groups in the same period (Table 1). The SFP lowered serum Triglyceride level and increased serum $\mathrm{Ca}, \mathrm{Na}, \mathrm{K}$, Albumin and Chloride. The observation is consistent with that of [37], who reported that dill and hemp seed abundant in flavonoids significantly decreased the serum triglyceride levels in the final broiler growth stage. Similarly, our results are in agreement with [38], who stated that the supplementation of Chinese bayberry leaves in chickens' diets significantly decreased the serum concentrations of triglycerides and cholesterol. Similar results are reported [39], who indicated that dietary supplementation of broilers with fermented Ginkgo biloba rations and fermented Ginkgo biloba leaves considerably dwindled the serum levels of triglycerides and cholesterol. It is postulated that one of the mechanisms responsible for a decrease in cholesterol level in chicks is via elevated biliary cholesterol excretion. Hence, supplementation of the shea fruit pulp in the broiler feed could lead to the development of low-cholesterol poultry products as demanded by health-conscious consumers.

Basit et al. [40] reported similar results when Persicaria odorata leaf meal (POLM) was used as feed supplement in broilers. The team reported serum levels of cholesterol and triglycerides decreased in comparison with the control group. However, POLM supplementation did not vary $(p>0.05)$ the serum level of $\mathrm{Na}, \mathrm{Cl}$, or glucose in the experimental birds.

One common factor employed for the assessment of the avian body condition applies to total plasma proteins [41]. It is largely acknowledged that plasma proteins of blood play significant roles in the upkeep of colloid osmotic pressure, as a speedy substitute for crucial amino acids, assuring glucose through gluconeogenesis, in the transport of minerals and hormones, in forming enzymes and the immune system in the organism [41]. Hence, plasma proteins of blood have a unique importance in homeostasis preservation. Additionally, it is noted that albumin, among the key serum proteins, functions as the utmost positive source of amino acids for the synthesis of tissue proteins in the period of quick somatic growth of birds, particularly under feed constrained conditions [41]. The research group revealed the content of protein in the blood serum of experimental chickens ranged from 33.00 to $47.80 \mathrm{~g} / \mathrm{l}$ and exhibited a persistent significant $(p<0.05)$ increase from the 14th to 42 nd day of administering the feed. 
It is worth mentioning that the total blood protein including its segments could be enormously adjustable in birds. A change in its levels has been reported to be contingent on many external and internal factors and result from the physiological role of blood proteins. It is suggested that the increasing concentration of total proteins and albumin between the 14th and 42nd day during the fattening period was possibly a direct consequence of the high demand for amino acids which are employed for very intensive somatic growth [42, 43]. Lipid metabolites are reported to be strongly linked to energy metabolism and reflect its fluctuation occurring during the administration of the supplement and the growth period during the experiment. Our study revealed that the serum triglyceride concentration of broilers in Group A fed with SFPMM meal peaked on the 21st day, reflecting intensive lipid metabolism and transport in the experimental broiler chickens. A report by Donkor et al. [44] indicated a similar trend when broilers were fed on leaves of Moringa oleifera maize meal (MOLMM). Further blood sampling (42nd day), a substantial reduction of triglyceride levels was observed when the meal was swapped to only $\mathrm{MM}$, and remained at a similar level until the end of the fattening period. Interestingly, there were fluctuations in triglyceride levels when broilers were initially fed on MM only for the first 21st days for the group B experimental broilers. In reported research, age-related changes, where serum triglyceride decreased significantly from the 2nd to 7 th weeks of lifespan, were detected in chickens. Nonetheless, other authors in experiments on growing chickens fed on standard diets observed quite the opposite, that is, a pattern of serum triglyceride increased with age. Prominent alterations in lipid blood metabolites were also found in an experiment on growing turkeys [42].

Minerals, essential for broiler growth, are involved in many digestive, physiological and biosynthetic processes within the body. $\mathrm{Ca}$ is considered as mainly necessary for the ossification of bones, regulation of muscle activity and catalyzation of enzyme and hormone systems whereas phosphorus is an essential constituent of nucleic acids and phospholipids [45]. Mg is enormously involved

Table 2 Proximate composition of Shea fruit pulp (mean \pm SD)

\begin{tabular}{lc}
\hline Parameter & Percentage $(\mathbf{w} / \mathbf{w})$ \\
\hline Moisture & $9.13 \pm 0.05$ \\
Crude protein & $10.34 \pm 0.15$ \\
Crude fiber & $26.62 \pm 0.11$ \\
Crude fat & $3.55 \pm 0.24$ \\
Ash & $9.23 \pm 0.08$ \\
Carbohydrates & $41.14 \pm 0.16$
\end{tabular}

SD Standard Deviation, $w / w$ weight per weight
Table 3 Essential mineral and heavy metal content of the Shea fruit pulp

\begin{tabular}{lll}
\hline Nutrient & Concentration $(\mathbf{m g} / \mathbf{l})$ & Concentration $\mathbf{( m g / ~} \mathbf{~ 0 0} \mathbf{g})$ \\
\hline $\mathrm{Ca}$ & 11.74 & 587.00 \\
$\mathrm{Na}$ & 2.76 & 138.30 \\
$\mathrm{Mg}$ & 27.16 & 1358.00 \\
$\mathrm{~K}$ & 15.43 & 771.50 \\
$\mathrm{Fe}$ & 0.59 & 29.88 \\
$\mathrm{Zn}$ & 0.81 & 40.31 \\
$\mathrm{Cu}$ & 0.16 & 8.11 \\
$\mathrm{~Pb}$ & $\mathrm{BDL}$ & $\mathrm{BDL}$ \\
$\mathrm{Cr}$ & $\mathrm{BDL}$ & $\mathrm{BDL}$ \\
$\mathrm{Mn}$ & $\mathrm{BDL}$ & $\mathrm{BDL}$ \\
$\mathrm{Cd}$ & $\mathrm{BDL}$ & $\mathrm{BDL}$
\end{tabular}

BDL Below detectable levels $(0.0001 \mathrm{mg} / \mathrm{l})$

in metabolism, typically as a catalyst of a wide range of enzymes, and iron is a necessary constituent of hemoglobin, myoglobin and cytochrome enzymes [45].

The outcome of the current study showed a substantial increase in Ca content of all the experimental groups related to the broiler chickens at the end of the fattening period. Previous studies concerning $\mathrm{Ca}$ and $\mathrm{P}$ contents in serum with respect to the age of chickens are varied. One research group reported noticeable increasing trend in the first 2-4 weeks of age while others revealed only fluctuation during the entire fattening period. The group indicated that rapid bone development and mineralization might exhibit $\mathrm{Ca}$ content between the 14th to 21st days of experimental broilers [46].

\section{Proximate and mineral composition of the shea fruit pulp}

The results of the proximate analysis (moisture, crude fiber, crude protein, crude fat, ash and carbohydrate) regarding the SPF are summarized in Table 2. The dried powdered shea fruit pulp of Vitellaria paradoxa contain approximately $10.34 \%$ crude protein, $3.55 \%$ crude fat, $26.62 \%$ crude fiber, $9.23 \%$ ash, $9.13 \%$ moisture and $41.14 \%$ carbohydrate.

The SFP has shown to be a good source of essential nutritional minerals required for healthy growth (Table 3 ). Heavy metals such Cd, Pd, Mn and Cr, which can be toxic to the body when ingested, were estimated to be below detectable limits; depicting that SFP might be considered as safe for consumption. The SPF mineral contents were found to be higher, with the exception of Fe, compared with the values reported previously on mineral analysis of apple (Anisophyllea laurina R. Br. ex Sabine) by Shajib et al. [47], who reported $778 \mu \mathrm{g} / 100 \mathrm{~g}$ for iron, $350 \mathrm{mg} / 100 \mathrm{~g}$ for potassium, $2025 \mu \mathrm{g} / 100 \mathrm{~g}$ for manganese, $23.6 \mathrm{mg} / 100 \mathrm{~g}$ for magnesium and $66.6 \mathrm{mg} / 100 \mathrm{~g}$ for calcium. The values for sodium content in monkey apple fruit pulp $(17.03 \mathrm{mg} / 100 \mathrm{~g})$ and that of calcium 
(185.49 mg/100 g) were lower compared with that of SFP. However, the mineral element in apple fruit, such as $\mathrm{Ca}, \mathrm{Na}$ and $\mathrm{K}$ were found to be higher than the values which have been re-counted earlier [48]. Gani et al. [49] reported the contents of $\mathrm{Na}(9.23 \mathrm{mg} / 100 \mathrm{~g})$ and $\mathrm{Fe}$ $(12.40 \mathrm{mg} / 100 \mathrm{~g})$ for cherry was comparably lower than that determined in SFP.

Additionally, $\mathrm{Mg}$ recorded the highest amount of mineral composition $(1358 \mathrm{mg} / 100 \mathrm{~g})$, in SFP compared to the value of $11 \mathrm{lmg} / 100 \mathrm{~g}$ reported by Mbaiguinam et al. [21]; $0.5 \mathrm{mg} / 100 \mathrm{~g}$ by Aguzue et al. [19] and the range $44.9-107.2 \mathrm{mg} / 100 \mathrm{~g}$ reported by Ugese et al. [50] in a diet-related experiment in broiler chickens. SFP was found to be devoid of would-be lethal elements such as $\mathrm{Mn}, \mathrm{Cd}, \mathrm{Cr}$ and $\mathrm{Pb}$ substantiating its potential as feed supplement for broilers. Minerals in typical poultry feed formulations are said to be delivered principally in the inorganic form [51]. The report indicated that novel forms are being introduced, where minerals are being used in chelated and organic forms for better delivery, absorption, utilization and conversion efficiency.

\section{Conclusion}

The demand for using an alternative natural feed additive such as nutraceuticals is critical especially after precluding using of antibiotics in poultry feed as growth factors.

The results obtained revealed that the shea fruit pulp contains important macronutrients and vital biochemical minerals and hence could be a potential feed source for poultry. The Shea tree with its fruit pulp is locally available and could be used alternatively in place of commercially produced poultry feeds, which are very expensive. Poultry feed formulated with shea fruit pulp is considered to have contributed to the improvement of the weight performance of poultry and their physiological status. There were no observable detrimental effects of the fruit pulp on the health of the experimental broilers during the course of the experimental period. Heavy metals such as $\mathrm{Cd}, \mathrm{Pb}, \mathrm{Mn}$ and $\mathrm{Cr}$ which are potentially toxic to biological systems including broilers above certain limits were also found to be below detectable levels after analysis of the shea fruit pulp and thus potentially safe for usage in poultry feeds.

\footnotetext{
Acknowledgements

The authors are grateful to the Department of Applied Chemistry \& Biochemistry, C. K. Tedam University of Technology and Applied Sciences, Navrongo, for providing the Atomic Absorption Spectrophotometer (AAS) and some other materials used in this study. We appreciate the following individuals and institutions for their support and making their facilities available during the course of this work: Mr. Taylor Addah of Navrongo Veterinary Institute; Iqurate Laboratory Consult Ltd., Bolgatanga; Mr. Elorm of the Food Science Laboratory, Kwame Nkrumah University of Science and Technology (KNUST), Kumasi.
}

\section{Authors' contributions}

AMD, RM conceived and planned the research work; RM collected and processed the plant material. EAA and KC conducted the experimentations; MND analyzed and interpreted the data; AMD, MND, RM, EAA, KC and FA contributed correspondingly in conscripting and writing the manuscript. All authors read and approved the final manuscript.

\section{Funding}

Not applicable.

\section{Availability of data and materials}

The datasets used and/or analyzed during the current study are available from the corresponding author on reasonable request.

\section{Declarations}

\section{Ethics approval and consent to participate}

All procedures with animals in the study were conducted in accordance with national or institutional guidelines for the care and use of animals and the ethical standards of the institution or practice. Blood samples were collected as per standard sampling procedure without any harm to the animals. The approval from the Institutional Animal Ethics Committee was not required; the study did not affect the normal animal physiology.

\section{Consent for publication}

Not applicable.

\section{Competing interests}

The authors declare that they have no competing interests.

\section{Author details}

'Department of Applied Chemistry and Biochemistry, Faculty of Applied Sciences, C. K. Tedam University of Technology and Applied Sciences, Navrongo, Ghana. ${ }^{2}$ Department of Applied Biology, Faculty of Applied Sciences, C. K. Tedam University of Technology and Applied Sciences, Navrongo, Ghana.

${ }^{3}$ Faculty of Pharmaceutical Sciences, School of Pharmacy and Pharmaceutical Sciences, University for Development Studies, Tamale, Ghana. ${ }^{4}$ Department of Food Biotechnology, Faculty of Agriculture, Food and Consumer Sciences, University for Development Studies, Tamale, Ghana.

Received: 16 January 2021 Accepted: 8 July 2021

Published online: 29 November 2021

\section{References}

1. Atuahene C, Attoh-Kotoku V, Mensah J. Poultry production in Ghana: Prospects and challenges. Ghana J Anim Sci. 2012;5:93-9.

2. Ministry of Food and Agriculture (MoFaA). Ghana livestock development policy and strateg. Accra, Ghana. 2016. http://www.e-agriculture.gov.gh/ index.php/policies/133-ghana-livestock-development-policy-and-strat egy. Accessed 3 Sept 2020.

3. Agyei-Henaku KA. Ghana news: Challenges of the poultry industry in Ghana. 2016. http://www.graphic.com.gh/business/business-news/chall enges-of-the-poultry-industry-in-ghana-graphic-online.pdf. Accessed 19 Aug 2020.

4. Abu O, Olaleru I, Oke T, Adepegba V, Usman B. Performance of broiler chicken fed diets containing cassava peel and leaf meals as replacements for maize and soya bean meal. Int J Sci Technol. 2015;4(4):169-73.

5. Schneider K, Plotnick R. Poultry market in West Africa: overview and comparative analysis. EPAR Brief. 2010;82:1-26.

6. Dei H, Mesuna S, Otchere E, Djang-Fordjour K, Agbolosu A, Frey E. A preliminary study on growth response of broiler finishers fed processed mottle Mucuna beans (Mucuna pruriens var. utilis). Ghana J Dev Stud. 2006;3(1):35-43.

7. Adejinmi O, Adejinmi J, Adeleye I. Replacement value of fish meal with soldier fly larvae meal in broiler diets. Nigerian Poult Sci J . 2000;1:52-60

8. Orogun AJ, Oniye SJ, Olugbemi TS. Growth response and haematological characteristics of broilers fed diets containing shea butter (Vitellaria 
paradoxa C.F Gaertn) seed cake as starter. Int I Sci Res Sci Eng Technol. 2015;1(2):304-10.

9. Buamah T. Feeding Chicken for egg production. Accra: Ghana Publishing Corporation; 1992.

10. Osei S, Atuahene C, Donkoh A, Kwarteng K, Ahenkora K, Dzah B, et al. editors. Further studies on the use of QPM as a feed ingredient for broiler chickens. Proc Ghana Anim Sci Assoc Symp. 1994;22:51-5.

11. Okai D, Olympio O, Bonsi M, Sam E. Poultry and Pig Production Handbook for the Ghanaian Farmer. Kumasi: Degraft Graphics and Pub; 1989.

12. Amata I. The use of non-conventional feed resources (NCFR) for livestock feeding in the tropics: a review. J Glob Biosci. 2014;3(2):604-13.

13. Hall JB, Aebischer DP, Tomlinson HF, Osei-Amaning E, Hindle JR. Vitellaria paradoxa. Schl Agricu Forest Sci Publ . 1996;8:1-105.

14. Dei HK, Rose S, Mackenzie A. Shea nut (Vitellaria paradoxa) meal as a feed ingredient for poultry. Worlds Poult Sci J. 2007;63(4):611-24.

15. Abidemi TA, Adebayo O, Idowu O, Agbotoba M. Nutrient content and anti-nutritional factors in shea butter (Butryospermum parkii) leaves. Afr J Biotechnol. 2009. https://doi.org/10.5897/AJB09.593).

16. Dennie MN. Medical Benefits of the Shea Nut Tree. Biology Student Research. 1. 2012. https://digitalscholarship.tnstate.edu/biology_stude nts/1. Accessed 15 Sept 2020.

17. Abbiw DK. Useful Plants of Ghana: West African Uses of Wild and Cultivated Plants. London: Intermediate Technology Publications, Royal Botanic Gardens, Kew; 1990.

18. Ugese FD, Baiyeri PK, Mbah BN. Nutritional composition of shea (Vitellaria paradoxa) fruit pulp across its major distribution zones in Nigeria. Fruits. 2008;63(3):163-70.

19. Aguzue O, Akanji F, Tafida M, Kamal M. Nutritional and some elemental composition of shea (Vitellaria paradoxa) fruit pulp. Arch Appl Sci Res. 2013;5:63-5.

20. Maranz S, Kpikpi W, Wiesman Z, De Saint SA, Chapagain B. Nutritional values and indigenous preferences for shea fruits (Vitellaria paradoxa CF Gaertn. F) in African Agroforestry Parklands. Econ Bot. 2004;58(4):588-600.

21. Mbaiguinam M, Mbayhoudel K, Djekota C. Physical and chemical characteristics of fruits, pulps, kernels and butter of shea Butyrospermum parkii (Sapotaceae) from Mandoul. Southern Chad Asian J Biochem. 2007;2:101-10.

22. Okullo J, Omujal F, Agea J, Vuzi P, Namutebi A, Okello J, et al. Proximate and mineral composition of shea (Vitellaria paradoxa CF Gaertn) fruit pulp in Uganda. Afr J Food Agric Nutr Dev. 2010. https://doi.org/10.4314/ ajfand.v10i11.64286.

23. Onyimonyi A, Olabode A, Okeke G. Performance and economic characteristics of broilers fed varying dietary levels of neem leaf meal (Azadirachta indica). Int J Poult Sci. 2009:8(3):256-9.

24. Association of Official Analytical Chemists (AOAC). Official methods of analysis. 17th ed. Washington: Association of Official Analytical Chemists; 2000.

25. Jahanbakhshi A, Yeganeh R, Momeny M. Influence of ultrasound pretreatment and temperature on the quality and thermodynamic properties in the drying process of nectarine slices in a hot air dryer. J Food Process Preserv. 2020;44(10):e14818.

26. Kaveh $\mathrm{M}$, Karami $\mathrm{H}$, Jahanbakhshi A. Investigation of mass transfer, thermodynamics, and greenhouse gases properties in pennyroyal drying. J Food Process Eng. 2020;43(8):e13446.

27. Okonwu K, Enyinnaya A. Comparative phytochemical studies and proximate analysis of five commonly consumed vegetables of Southern Nigeria. Asian J Biol. 2016;1:1-7.

28. Hussain J, Rehman N, Khan AL, Hussain H, Al-Harrasi A, Ali L, et al. Determination of macro and micronutrients and nutritional prospects of six vegetable species of Mardan. Pakistan Pak J Bot. 2011;43(6):2829-33.

29. Ferket PR, Gernat AG. Factors that affect feed intake of meat birds: A review. Int J Poult Sci. 2006;5(10):905-11.

30. Rhoads M, Rhoads R, Van Baale M, Collier RJ, Sanders S, Weber W, et al. Effects of heat stress and plane of nutrition on lactating Holstein cows: I. Production, metabolism, and aspects of circulating somatotropin. J Dairy Sci. 2009;92(5):1986-97.

31. Koelkebeck KW. Physiological responses of poultry to the environment. Illinois: College of Agriculture, Consumer and Environmental Sciences, University of Illinois at Urbana-Champaign, Illinois-poultrynet; 2001. p. 1-4.

32. Sohail M, Hume M, Byrd J, Nisbet D, ljaz A, Sohail A, et al. Effect of supplementation of prebiotic mannan-oligosaccharides and probiotic mixture on growth performance of broilers subjected to chronic heat stress. Poult Sci. 2012;91(9):2235-40.

33. Zhu Y, Cheng J, Ren M, Yin L, Piao X. Effect of Y-aminobutyric acid-producing Lactobacillus strain on laying performance, egg quality and serum enzyme activity in Hy-Line brown hens under heat stress. Asian-Australas J Anim Sci. 2015;28(7):1006.

34. dos Santos T, Dassi S, Franco C, da Costa C, Lee S, da Silva A. Influence of fibre and betaine on development of the gastrointestinal tract of broilers between hatch and $14 \mathrm{~d}$ of age. Anim Nutr. 2019;5(2):163-73.

35. Food and Agriculture Organization (FAO). Quality Assurance for Animal Feed Analysis Laboratories. Rome: FAO Animal Production and Health Manual No 14; 2011.

36. Mateos G, Jiménez-Moreno E, Serrano M, Lázaro R. Poultry response to high levels of dietary fiber sources varying in physical and chemical characteristics. J Appl Poult Res. 2012;21(1):156-74.

37. Vispute M, Sharma D, Mandal A, Rokade J, Tyagi P, Yadav A. Effect of dietary supplementation of hemp (Cannabis sativa) and dill seed (Anethum graveolens) on performance, serum biochemicals and gut health of broiler chickens. J Anim Physiol Anim Nutr (Berl). 2019;103(2):525-33.

38. Zhang Y, Chen S, Wei C, Chen J, Ye X. Proanthocyanidins from Chinese bayberry (Myrica rubra Sieb. et Zucc.) leaves regulate lipid metabolism and glucose consumption by activating AMPK pathway in HepG2 cells. J Funct Foods. 2017;29:217-25.

39. Niu $Y$, Zhang J, Wan $X$, Huang Q, He J, Zhang $X$, et al. Effect of fermented Ginkgo biloba leaves on nutrient utilisation, intestinal digestive function and antioxidant capacity in broilers. Br Poult Sci. 2019;60(1):47-55.

40. Abdul Basit M, Abdul Kadir A, Loh TC, Abdul Aziz S, Salleh A, Kaka U, et al. Effects of Inclusion of Different Doses of Persicaria odorata Leaf Meal (POLM) in broiler chicken feed on biochemical and haematological blood indicators and liver histomorphological changes. Animals (Basil). 2020;10(7):1209.

41. Yaman M, Kita K, Okumura J. Different responses of protein synthesis to refeeding in various muscles of fasted chicks. Br Poult Sci. 2000;41:224-8.

42. Szabó A, Mezes M, Horn P, Sütő Z, Bázár G, Romvari R. Developmental dynamics of some blood biochemical parameters in the growing turkey (Meleagris gallopavo). Acta Vet Hung. 2005;53(4):397-409.

43. Filipović N, Stojević Z, Milinković-Tur S, Ljubić B, Zdelar-Tuk M. Changes in concentration and fractions of blood serum proteins of chickens during fattening. Veterinarski Arhiv. 2007;77(4):319-26.

44. Donkor A-M, Glover R, Addae D, Kubi K. Estimating the nutritional value of the leaves of Moringa oleifera on poultry. Food Nutr Sc. 2013;04(11):1077-83.

45. Piotrowska A, Burlikowska K, Szymeczko R. Changes in blood chemistry in broiler chickens during the fattening period. Folia Biol. 2011;59(3-4):183-7.

46. Williams B, Solomon S, Waddington D, Thorp B, Farquharson C. Skeletal development in the meat-type chicken. Br Poult Sci. 2000;41(2):141-9.

47. Shajib MT, Kawser M, Miah MN, Begum P, Bhattacharjee L, Hossain A, et al. Nutritional composition of minor indigenous fruits: cheapest nutritional source for the rural people of Bangladesh. Food Chem. 2013;140(3):466-70

48. Onivogui G, Zhang H, Mlyuka E, Diaby M, Song Y. Chemical composition, nutritional properties and antioxidant activity of monkey apple (Anisophyllea laurina R. Br. ex Sabine). J Food Nutr Res. 2014;2(6):281-7.

49. Gani M, Jabeen A, Majeed D, Mir S, Dar B. Proximate composition, mineral analysis and antioxidant capacity of indigenous fruits and vegetables from temperate region of Indian Himalayas. Food Measure. 2018;12(2):1011-9.

50. Ugese FD, Baiyeri K, Mbah BN. Mineral content of the pulp of shea butter fruit (Vitellaria paradoxa CF Gaertn.) sourced from seven locations in the savanna ecology of Nigeria. Tree For Sci Biotechnol. 2008;2:40-2.

51. Alagawany M, Elnesr S, Farag M, Tiwari R, Yatoo M, Karthik K, et al. Nutritional significance of amino acids, vitamins and minerals as nutraceuticals in poultry production and health-a comprehensive review. Vet Q. 2021;41(1):1-29.

\section{Publisher's Note}

Springer Nature remains neutral with regard to jurisdictional claims in published maps and institutional affiliations. 